\title{
Pathogenic diversity of soybean rust in Argentina, Brazil, and Paraguay
}

\author{
Hajime Akamatsu - Naoki Yamanaka - Yuichi Yamaoka • Rafael Moreira Soares • \\ Wilfrido Morel • Antonio Juan Gerardo Ivancovich • Alicia Noelia Bogado • \\ Masayasu Kato · José Tadashi Yorinori · Kazuhiro Suenaga
}

Received: 25 May 2012/ Accepted: 17 October 2012/Published online: 30 November 2012

(C) The Phytopathological Society of Japan and Springer Japan 2012

\begin{abstract}
Phakopsora pachyrhizi, the cause of soybean rust, is an economically important pathogen of soybean in South America. Understanding the pathogenicity of indigenous fungal populations is useful for identifying resistant plant genotypes and targeting effective cultivars against certain populations. Fifty-nine rust populations from Argentina, Brazil, and Paraguay were evaluated for pathogenicity in three cropping seasons, 2007/2008-2009/ 2010, using 16 soybean differentials. Only two pairs of $P$. pachyrhizi populations displayed identical pathogenicity profiles, indicating substantial pathogenic variation in the rust populations. Comparative analysis of 59 South American and five Japanese samples revealed that pathogenic differences were not only detected within South America but also distinct between the $P$. pachyrhizi populations from South America and Japan. In addition, seasonal changes in rust pathogenicity were detected during
\end{abstract}

H. Akamatsu $(\bowtie) \cdot$ N. Yamanaka $\cdot$ M. Kato $\cdot$ K. Suenaga Biological Resources and Post-harvest Division, Japan International Research Center for Agricultural Sciences (JIRCAS), 1-1 Ohwashi, Tsukuba, Ibaraki 305-8686, Japan e-mail: akamatho@affrc.go.jp

\section{Y. Yamaoka}

Faculty of Life and Environmental Sciences, University of Tsukuba, 1-1-1 Tennodai, Tsukuba, Ibaraki 305-8572, Japan

R. M. Soares · J. T. Yorinori

National Soybean Research Center (EMBRAPA Soja), Brazilian Agricultural Research Corporation (EMBRAPA), Londrina, Paraná 86001-970, Brazil

W. Morel · A. N. Bogado

Research Center of Capitán Miranda (CICM) (formerly Regional Center for Agricultural Research in Capitán Miranda [CRIA]), The Paraguayan Institute of Agrarian Technology (IPTA),

Capitán Miranda, Itapúa, Paraguay the sampling period. The differentials containing resistance genes (Rpp: resistance to $\underline{P}$. pachyrhizi) Rpp1, Rpp2, Rpp3, and Rpp4, except for Plant Introduction (PI) 587880A, displayed a resistant reaction to only $1.8-14,24-28,22$, and $36 \%$ of South American P. pachyrhizi populations, respectively. In contrast, PI 587880A (Rppl), Shiranui (Rpp5), and 3 Rpp-unknown differentials (PI 587855, PI 587905, and PI 594767A) showed a resistant reaction to 78-96 \% of all populations. This study demonstrated that P. pachyrhizi populations from South America vary geographically and temporally in pathogenicity and that the known Rpp genes other than Rppl in PI 587880A and Rpp5 have been less effective against recent pathogen populations in the countries studied.

Keywords Basidiomycete - Cluster analysis - Glycine max . Obligate biotroph $\cdot$ Virulence

A. J. G. Ivancovich

Agricultural Experimental Station-Pergamino (EEA-Pergamino), National Institute of Agricultural Technology (INTA),

Pergamino, Buenos Aires, Argentina

Present Address:

M. Kato

National Agriculture and Food Research Organization

Agricultural Research Center (NARO/ARC), National

Agriculture and Food Research Organization (NARO), 3-1-1

Kannondai, Tsukuba, Ibaraki 305-8666, Japan

Present Address:

J. T. Yorinori

Tadashi Agro, Rua Campo Largo 170, Jardim Santo Antônio,

Londrina, Paraná 86060-560, Brazil 


\section{Introduction}

Newly appearing pathogens often cause tremendous yield losses in their target crops and become an economic threat in agriculture. Soybean [Glycine max (L.) Merrill] is an economically important crop and is a valuable source of oil and protein worldwide as well as of food products traditional to the Orient. South American countries are the largest soybean producers in the world (FAOSTAT 2008), with production centered in Brazil, Argentina, and Paraguay. Since the first outbreak of soybean rust, caused by Phakopsora pachyrhizi Sydow \& P. Sydow, in Paraguay and Brazil in 2001 and in Argentina in 2003 (Ivancovich 2005; Yorinori et al. 2005), it has been one of the most serious foliar diseases in South America. In 2004, soybean rust reached the United States (Schneider et al. 2005), and movement of the pathogen from South America to North America was believed to be facilitated by Hurricane Ivan (Isard et al. 2005). Approximately $90 \%$ of total world soybean production is from North and South America. The common occurrence of the disease in South America and the possible long-distance transmissibility of the urediniospores (Isard et al. 2005) enable the fungus to inflict large losses in soybean yield and economic damage to soybean-related industries in North and South American countries. Currently, soybean rust is of great concern not only in North and South America but also around the world.

Planting soybean-rust-resistant varieties, one of the currently adopted strategies for disease management, is more economical and environmentally friendly than chemical control. Five major resistance loci (Rpp: resistance to $\underline{P}$. pachyrhizi), named Rppl to Rpp5, confer resistance to specific isolates of $P$. pachyrhizi (Garcia et al. 2008). Recently, a new Rpp locus that provides resistance to $P$. pachyrhizi isolates from both Paraguay and the United States has been identified as Rpp6 (Li et al. 2012). These $R p p$ genes are known to condition resistance to specific P. pachyrhizi isolates (Hartman et al. 2005; Miles et al. 2011). Two types of resistant reactions in soybean have been reported: one is an immune reaction that produces no visible symptoms, and the other produces reddish-brown (RB) lesions (Bromfield 1984). The RB lesions accompany the formation of uredinia and urediniospores, thus the resistance is incomplete (Miles et al. 2011). In contrast, a compatible interaction between soybean and $P$. pachyrhizi results in tan-colored (TAN) lesions with more uredinia and higher sporulation than in interactions with RB lesions.

Resistance conferred by a single dominant gene has usually not been durable because of its specificity against a limited number of pathogenic strains (races). Rpp genes in the soybean- $P$. pachyrhizi interaction are no exception; breakdown of resistance in the cultivars harboring an $R p p$ gene has been reported to occur several years after field release of these cultivars (Bromfield 1984; Hartman et al. 2005; Yeh 1983). In Brazil, four Rpp genes, Rppl-Rpp4, were effective against the disease in 2001 when the rust first appeared, but the Rppl- and Rpp3-conferred resistances have been defeated by the pathogen within a few years (Yorinori 2008). This short-term durability of $R p p$ resistance genes may reflect pathogenic variability and the development of new pathogenic strains (races) in field populations of $P$. pachyrhizi.

Physiological races of $P$. pachyrhizi were determined using a specific set of differential plants, mainly of Glycine spp. Pathogenic variation in $P$. pachyrhizi has been reported in several countries since the first description of races in Taiwan (Lin 1966). In Japan, where the disease has been common for 100 years, 18 races were identified in 45 rust isolates from soybean, Pueraria lobata, and Glycine soja (Yamaoka et al. 2002). In Nigeria, a country with relatively little experience of the epidemic, Twizeyimana et al. (2009) classified 116 P. pachyrhizi isolates into seven pathotype clusters displaying considerable differences in the $P$. pachyrhizi pathotype composition. In a more recent collection of the United States isolates, three pathotypes and six aggressiveness groups were found (Twizeyimana and Hartman 2012). Comparison of pathogenicity in isolates representing different geographical and temporal origins revealed that newer $P$. pachyrhizi isolates collected in Africa and South America in 2001 were more virulent than older ones collected in Asia and Australia in the 1970s (Bonde et al. 2006). A distinct difference in pathogenicity was found between Brazilian and Japanese P. pachyrhizi, in which Brazilian rust populations were more virulent than the Japanese one (Yamanaka et al. 2010). Such knowledge of the pathogenic variation of the fungus is necessary for finding useful genetic sources to reduce disease and for developing rust-resistant soybean cultivars for specific regions.

Pathogenicity or virulence typing has been performed in only a limited number of $P$. pachyrhizi samples from Brazil and Paraguay (Bonde et al. 2006; Kato and Yorinori 2008; Miles et al. 2011; Pham et al. 2009; Yamanaka et al. 2010; Yorinori 2008). Because the currently available data about $P$. pachyrhizi pathogenicity and/or virulence are based on different evaluation methods, little is known about the differentiation in pathogenicity of this fungus in South America. This study represents the first elucidation of pathogenic variation in $P$. pachyrhizi from Argentina, Brazil, and Paraguay, using an evaluation method and index modified from Yamanaka et al. (2010). The objective of this study was to investigate geographical and seasonal variation in pathogenicity of $P$. pachyrhizi infecting soybean in the three South American countries. 


\section{Materials and methods}

Soybean rust sampling

Soybean rust populations were collected in Argentina, Brazil, and Paraguay in the cropping seasons of 2007/2008, 2008/2009, and 2009/2010 (Fig. 1; Table 1). Sixteen rust populations were collected from 12 locations in Argentina: Buenos Aires, Santa Fé, and Entre Rios provinces in the Pampa region, Misiones, Formosa, and Chaco provinces in the Northeast region, and Santiago del Estero, Tucumán, Salta, and Jujuy provinces in the Northwest region (Fig. 1a; Table 1). Twenty-four soybean rust populations including BRP-1 and BRP-2 (Yamanaka et al. 2010) were collected in seven states: Rio Grande do Sul and Paraná states in the South region, Minas Gerais state in the Southeast region, Mato Grosso do Sul, Mato Grosso, and Goiás states in the Central-West region, and Rondônia state in the North region, and the Federal District of Brazil (Fig. 1b; Table 1). In Paraguay, 19 rust populations were sampled from 15 locations of three prefectures, Canindeyú, Alto Paraná, and Itapúa (Fig. 1c; Table 1). To investigate pathogenic difference among dominant races rather than certain specific races in the samples, we used $P$. pachyrhizi populations without single-spore isolation in this study. For comparative analysis of soybean rust pathogenicity between South America and Japan, rust samples were collected in Japan in 2007 and 2008 (Table 1; Yamanaka et al. 2010). Urediniospores formed on the sampled leaves were harvested with a paintbrush or a vacuum-type collector and transferred to $2 \mathrm{~mL}$ of cryogenic tubes (Greiner Bio-One, Frickenhausen, Germany). The cryogenic tubes with caps opened were placed into a desiccator containing silica gel. After 1 day, these tubes were stored in a $-80{ }^{\circ} \mathrm{C}$ ultra freezer or liquid nitrogen.

Inoculation and data collection

Sixteen soybean differentials (Table 2) were inoculated with a urediniospore suspension $\left(5 \times 10^{4}\right.$ spores $\left./ \mathrm{mL}\right)$ of $P$. pachyrhizi using a paintbrush or glass atomizer. The urediniospore suspension and differential plants were prepared according to Yamanaka et al. (2010).

Two weeks after inoculation, lesion appearance [presence $(+)$ or absence $(-)$ of lesions] and sporulation level (SL) on the differential set were determined macroscopically. The SL was rated using a 0-3 scale: 0 , none; 1 , little; 2, moderate; and 3, abundant (Fig. 2). This rating scale is similar to that for microscopic evaluation of SL reported by Yamanaka et al. (2010). Infection of the highly susceptible BRS 154 (differential 14; Table 2) with most of the rust samples resulted in the highest level of sporulation $(\mathrm{SL}=3$; Fig. 2). A few soybean leaves for each differential were detached from the inoculated plants, and the number of uredinia per lesion (NoU) in 30 lesions on the abaxial side of leaves of each differential was counted using a stereomicroscope. Data for the three variables, (1) presence $(+)$ or absence ( - ) of lesions, (2) SL, and (3) NoU, were collected for all rust populations and converted into infection types caused by the rust populations (Table 3 ). Infection types without lesions (immune) and with lesions with SL 0 or 1 and NoU $<1.5$ were classified as resistant (R); those with lesions with SL 2 or 3 and $\mathrm{NoU} \geq 1.5$ were classified as susceptible (S). When lesions with SL 2 or 3 and $\mathrm{NoU}<1.5$ or SL 0 or 1 and $\mathrm{NoU} \geq 1.5$ were observed, the infection types were classified as intermediate (IM).

\section{Cluster analysis}

The R, IM, and S infection types were coded as 0,1 , and 2, respectively. Distance matrices were prepared by calculating the Euclidean distance between samples using $\mathrm{R}$ software version 2.13.0 (R Development Core Team 2011), and the resulting matrices were input into a hierarchical clustering function of the software. Dendrograms based on the minimum variance (Ward's) method were also constructed with R. An R package, pvclust, was run to assess uncertainty in the hierarchical cluster analysis, which calculates probability values ( $p$ values) for each cluster using bootstrap resampling techniques (Suzuki and Shimodaira 2006).

\section{Results}

Pathogenic variation in rust populations from the three South American countries

The infection types of 16 Argentinean, 24 Brazilian, and 19 Paraguayan populations on the 16 differentials are shown in Tables 4, 5, and 6, respectively. Phakopsora pachyrhizi populations from Argentina were highly virulent to the Rpp-carrying differentials except for differentials 7 and 10. For example, three populations (AP2-3, AW10-3, and AW11-3) caused a susceptible reaction in the Rpp1-Rpp4carrying differentials 1-6, and 11. AP2-2, AE7-1, and AE8-1 caused a susceptible reaction in not only the Rpp1Rpp3-carrying differentials $1-5$ but also the Rpp5-carrying differential 7. Population AW9-3 displayed a distinctive pathogenicity profile with resistant and susceptible reaction in differentials 2 and 10, respectively. Of the 24 Brazilian populations, BS2-2 was the most virulent on all 16 differentials, causing a resistant reaction only in differential 7 with Rpp5. Eight populations (BS2-2, BS2-3, BS3-1, BRP2, BC5-1(2), BC7-1, BC10-1, and BC11-1) never produced 

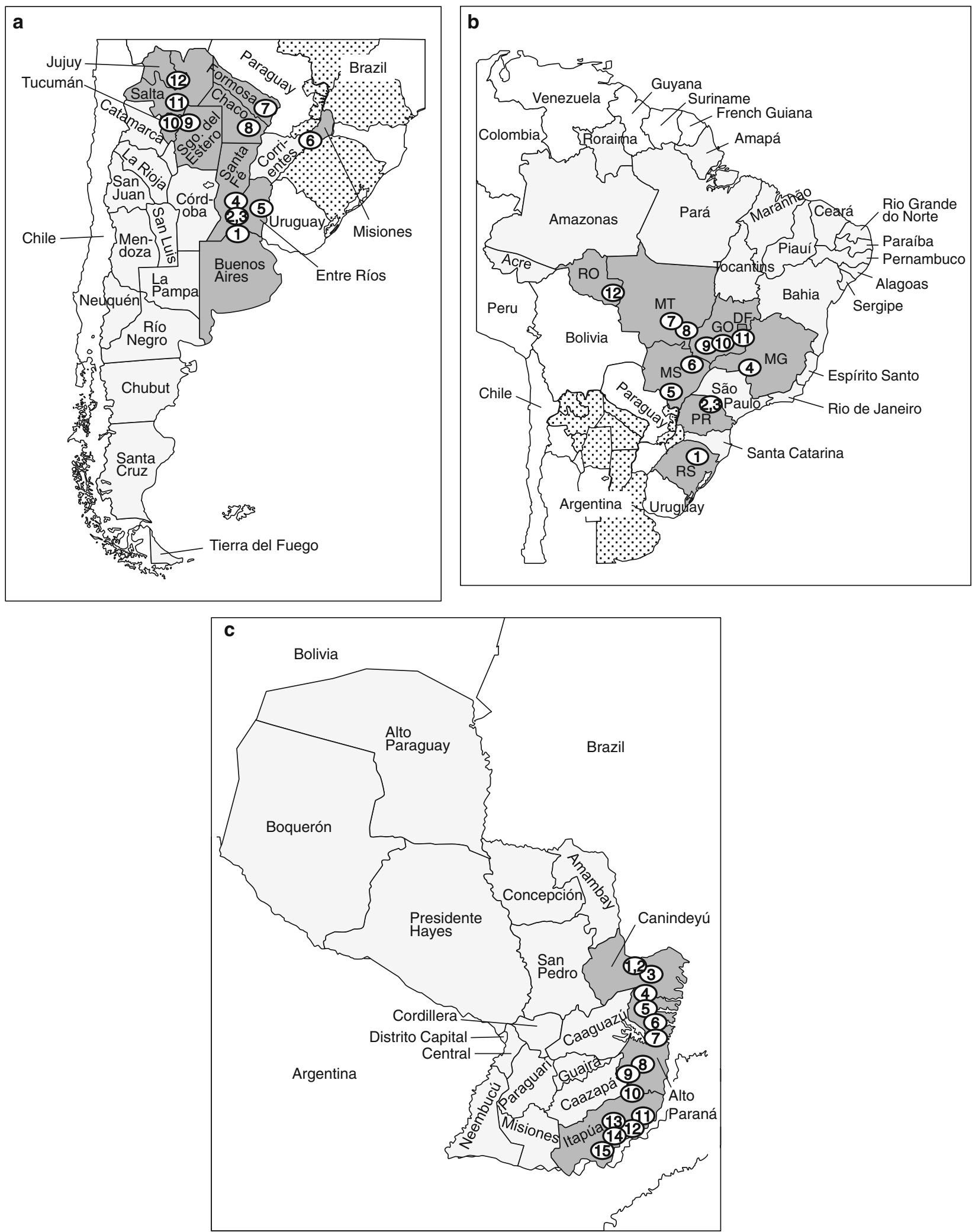

Fig. 1 Sampling locations of soybean rust in Argentina (a), Brazil (b), and Paraguay (c). Provinces of Argentina (a), states of Brazil (b), and prefectures of Paraguay (c) are shown on the map. Provinces, states, and prefectures from which the pathogen populations were obtained are indicated in dark gray, and others are indicated in light gray. a, b Ten provinces of Argentina, three states of Brazil, and three prefectures of Paraguay with the sampling locations are also indicated by dotted background. Blank maps of the three countries were downloaded from http://www.freemap.jp/ 
Table 1 Soybean rust samples used in this study
${ }^{a}$ Location numbers correspond to those in each country in Fig. 1

${ }^{b}$ Isolated from a field of EMBRAPA Soja, Londrina, PR, Brazil

${ }^{c}$ Isolated from greenhouses of EMBRAPA Soja, Londrina, PR, Brazil

d Two samples were isolated on different dates in the 2007/2008 season

e Isolated in 2007

${ }^{\mathrm{f}}$ Isolated in 2008

\begin{tabular}{|c|c|c|c|c|c|}
\hline \multirow[t]{3}{*}{ Country } & \multirow[t]{3}{*}{ No. $^{a}$} & \multirow[t]{3}{*}{ Location } & \multicolumn{3}{|c|}{ Sample code } \\
\hline & & & \multicolumn{3}{|c|}{ Soybean cropping season } \\
\hline & & & $2007 / 2008$ & $2008 / 2009$ & $2009 / 2010$ \\
\hline \multirow[t]{12}{*}{ Argentina } & 1 & Pergamino, Buenos Aires & AP1-1 & - & AP1-3 \\
\hline & 2 & Acebal, Santa Fé & - & AP2-2 & AP2-3 \\
\hline & 3 & Coronel Bogado, Santa Fé & - & - & AP3-3 \\
\hline & 4 & Rosario, Santa Fé & - & - & AP4-3 \\
\hline & 5 & Villa Mantero, Entre Rios & - & - & AP5-3 \\
\hline & 6 & Cerro Azul, Misiones & - & AE6-2 & AE6-3 \\
\hline & 7 & El Colorado, Formosa & AE7-1 & - & AE7-3 \\
\hline & 8 & Saenz Peña, Chaco & AE8-1 & - & - \\
\hline & 9 & Pozo Hondo, Santiago (Sgo.) del Estero & - & - & AW9-3 \\
\hline & 10 & Alderete, Tucumán & - & - & AW10-3 \\
\hline & 11 & Metán, Salta & - & - & AW11-3 \\
\hline & 12 & Ledesma, Jujuy & - & AW12-2 & - \\
\hline \multirow[t]{15}{*}{ Brazil } & 1 & Passo Fundo, Rio Grande do Sul (RS) & BS1-1 & BS1-2 & BS1-3 \\
\hline & 2 & Londrina, Paraná $(\mathrm{PR})^{\mathrm{b}}$ & BS2-1 & BS2-2 & BS2-3 \\
\hline & 3 & Londrina, Paraná $(\mathrm{PR})^{\mathrm{c}}$ & BS3-1 & - & - \\
\hline & & & BRP-1 & & \\
\hline & & & BRP-2 & & \\
\hline & 4 & Uberaba, Minas Gerais (MG) & - & BE4-2 & - \\
\hline & 5 & Dourados, Mato Grosso do Sul (MS) & BC5-1(1) ${ }^{\mathrm{d}}$ & - & $\mathrm{BC} 5-3$ \\
\hline & & & BC5-1(2) ${ }^{d}$ & & \\
\hline & 6 & Chapadão do Sul, MS & BC6-1 & - & - \\
\hline & 7 & Campo Verde, Mato Grosso (MT) & BC7-1 & - & - \\
\hline & 8 & Rondonópolis, MT & - & - & $\mathrm{BC} 8-3$ \\
\hline & 9 & Goiânia, Goiás (GO) & ВC9-1 & - & - \\
\hline & 10 & Senador Canedo, GO & BC10-1 & - & - \\
\hline & 11 & Planaltina, Distrito Federal (DF) & BC11-1 & BC11-2 & BC11-3 \\
\hline & 12 & Vilhena, Rondônia (RO) & BN12-1 & BN12-2 & BN12-3 \\
\hline \multirow[t]{15}{*}{ Paraguay } & 1 & Corpus Christi, Canindeyú & PC1-1 & - & - \\
\hline & 2 & Pindoty Porã, Canindeyú & PC2-1 & - & - \\
\hline & 3 & Katuete, Canindeyú & - & - & PC3-3 \\
\hline & 4 & Troncal, Alto Paraná & - & - & PA4-3 \\
\hline & 5 & Minga Porã, Alto Paraná & - & - & PA5-3 \\
\hline & 6 & San Alberto, Alto Paraná & PA6-1 & PA6-2 & - \\
\hline & 7 & Itakyry, Alto Paraná & - & - & PA7-3 \\
\hline & 8 & Santa Rita, Alto Paraná & - & PA8-2 & - \\
\hline & 9 & Naranjal, Alto Paraná & PA9-1 & - & - \\
\hline & 10 & Naranjito, Itapúa & PI10-1 & - & - \\
\hline & 11 & Maria Auxiliadora, Itapúa & - & - & PI11-3 \\
\hline & 12 & Capitán Meza, Itapúa & - & PI12-2 & - \\
\hline & 13 & Pirapó, Itapúa & PI13-1 & PI13-2 & - \\
\hline & 14 & Bella Vista, Itapúa & - & - & PI14-3 \\
\hline & 15 & Capitán Miranda, Itapúa & PI15-1 & PI15-2 & PI15-3 \\
\hline \multirow[t]{5}{*}{ Japan } & - & Kannondai, Tsukuba, Ibaraki & $J R P^{e}$ & - & - \\
\hline & - & Kannondai, Tsukuba, Ibaraki & $\mathrm{T} 1-2^{\mathrm{e}}$ & - & - \\
\hline & - & Kannondai, Tsukuba, Ibaraki & $\mathrm{N} 1-1^{\mathrm{e}}$ & - & - \\
\hline & - & Kannondai, Tsukuba, Ibaraki & $\mathrm{E} 1-4^{\mathrm{e}}$ & - & - \\
\hline & - & Kurihara, Tsukuba, Ibaraki & - & $\mathrm{N} 2-1^{\mathrm{f}}$ & - \\
\hline
\end{tabular}


Table 2 Soybean differentials used for the evaluation

\begin{tabular}{|c|c|c|c|c|c|}
\hline No. & Differential & Alternative & Rpp locus & Origin & References \\
\hline 1 & PI 200492 & Komata & Rppl & Japan & Hartwig and Bromfield (1983) \\
\hline 2 & PI 368039 & Tainung 4 & Rppl & Taiwan & McLean and Byth (1980) \\
\hline 3 & PI 230970 & No. 3 & Rpp2 & Japan & Hartwig and Bromfield (1983) \\
\hline 4 & PI 417125 & Kyushu 31 & Rpp2 & Japan & Laperuta et al. (2008) \\
\hline 5 & PI 462312 & Ankur & Rpp3 & India & Hartwig and Bromfield (1983) \\
\hline 6 & PI 459025 & Bing Nan & Rpp4 & China & Hartwig (1986) \\
\hline 7 & Shiranui & PI 200526 & Rpp5 & Japan & Garcia et al. (2008) \\
\hline 8 & PI 416764 & Akasaya & ND & Japan & Miles et al. (2006) \\
\hline 9 & PI 587855 & Jia Bai Jia & ND & China & \\
\hline 10 & PI 587880A & Huang Dou & Rppl & China & Ray et al. (2009) \\
\hline 11 & PI 587886 & Bai Dou & Rppl & China & Ray et al. (2009) \\
\hline 12 & PI 587905 & Xiao Huang Dou & ND & China & Miles et al. (2006) \\
\hline 13 & PI 594767A & Zhao Ping Hei Dou & ND & China & Miles et al. (2006) \\
\hline 14 & BRS 154 & & & Brazil & \\
\hline 15 & TK5 & Taita Kaohsiung No. 5 & ND & Taiwan & \\
\hline 16 & Wayne & PI 548628 & ND & USA & \\
\hline
\end{tabular}

$N D$ not determined
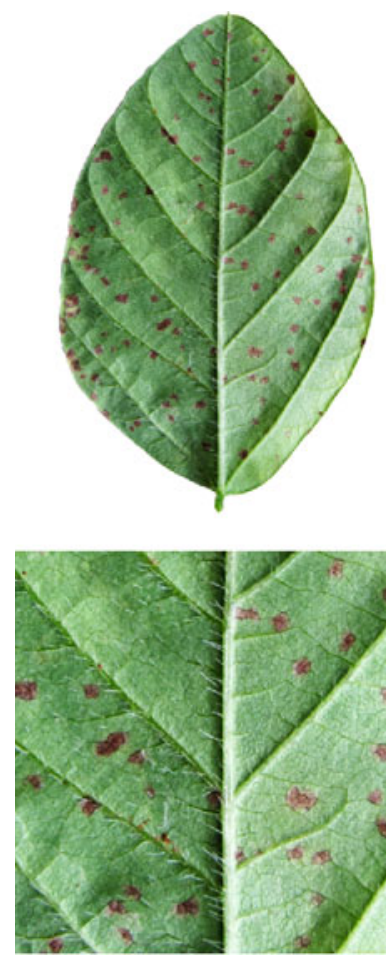

$\mathrm{SL}=0$

None
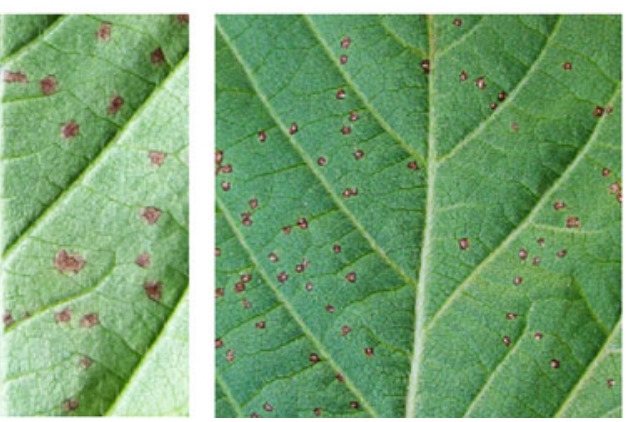

$\mathrm{SL}=1$

Little

Fig. 2 Macroscopic assessment of fungal sporulation on Phakopsora pachyrhizi-inoculated soybean leaves. The sporulation level (SL) was rated using a $0-3$ scale. The photos of the abaxial side of the leaves

a resistant reaction in any of the Rpp1-Rpp4-carrying differentials except for differential 10. Only 3, 5, and 4 populations from the South region of the country (BS1,
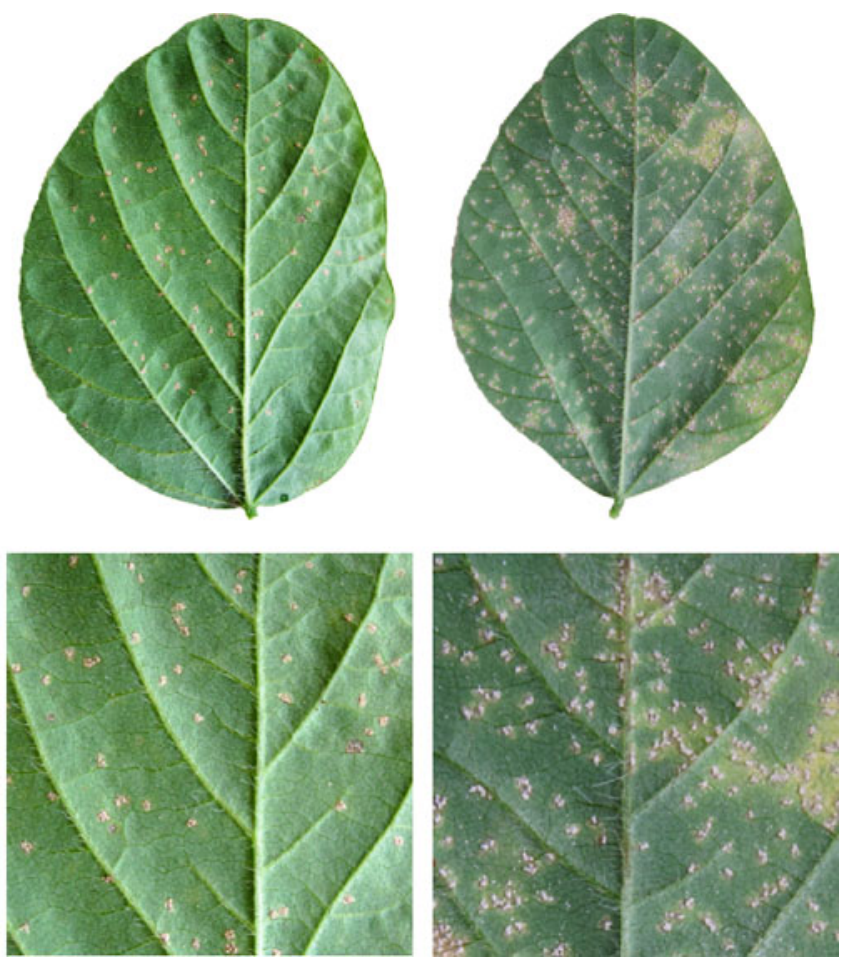

$\mathrm{SL}=2$

$\mathrm{SL}=3$

Moderate

Abundant

show examples of SL 0-3 from left to right: 0 , none; 1, little; 2, moderate; and 3, abundant

BS2, and BS3) caused a susceptible reaction in differentials 9, 10, and 12, respectively, and no Brazilian populations caused a susceptible reaction in differential 13. In 
Table 3 Classification of infection types produced by soybean rust

\begin{tabular}{llll}
\hline Lesion & $\mathrm{SL}$ & $\mathrm{NoU}^{\mathrm{a}}$ & Infection type \\
\hline- & - & - & $\mathrm{R}$ \\
+ & 0 or 1 & $<1.5$ & $\mathrm{R}$ \\
+ & 2 or 3 & $<1.5$ & $\mathrm{IM}$ \\
+ & 0 or 1 & 1.5 or more & $\mathrm{IM}$ \\
+ & 2 or 3 & 1.5 or more & $\mathrm{S}$ \\
\hline
\end{tabular}

$S L$ sporulation level, $R$ resistant, $I M$ intermediate, $S$ susceptible

${ }^{a}$ NoU: No. of uredinia per lesion, calculated from 30 lesions per differential

Paraguayan populations, PC1-1 and PA9-1 had an identical pathogenicity profile on the 16 differentials. Three populations (PC1-1, PA9-1, and PI15-1) from the 2007/2008 season produced a susceptible reaction in differentials 1-6 carrying Rppl to Rpp4. All seven populations from the 2007/2008 season produced a susceptible reaction in differentials $1-3$ and five carrying Rpp 1-Rpp3, while 12 populations from the following two seasons produced a resistant or intermediate reaction in some of the four differentials. Furthermore, some populations of the 2007/2008 season caused a susceptible reaction in differentials 7 and 9, which were resistant to all populations in the following two seasons.

Compared with P. pachyrhizi populations from South America, five rust samples from Japan were not highly virulent to the differentials, especially to the Rpp-carrying differentials (Table 4). E1-4 and N2-1 caused a resistant reaction in all nine differentials with five $R p p$ loci, while JRP, T1-2, and N1-1 caused a resistant reaction in the Rppcarrying differentials except for differentials 3 and 4 with Rpp2 and differential 11 with Rppl.

Cluster analysis yielded a dendrogram based on the pathogenicity of the 64 samples from South America and Japan (Fig. 3). Of the 59 South American populations analyzed, only two pairs of populations yielded identical pathogenicity profiles in the 16 differentials: BE4-2 and PA5-3 from Brazil and Paraguay, respectively, and PC1-1 and PA9-1 from Paraguay. Identical pathogenicity profiles in the differentials were also found among AP2-3 and AW10-3 from Argentina and PI15-1 from Paraguay, although rust reactions in only 14 differentials were available for the comparison. There were no combinations of Argentinean and Brazilian populations having an identical pathogenicity profile in the 59 populations. Some combinations of the rust populations with different country origins displayed similar pathogenicity profiles with a single response difference among the differentials, for example AW10-3 and BC7-1, AW11-3 and PI15-1, and BS1-2 and PC3-3. The dendrogram revealed that only a few South American populations with the same country origin formed subclusters, and no populations from South America fell into a subcluster containing Japanese rust samples. The 59 P. pachyrhizi populations from the three countries were scattered through the dendrogram, and no geographical association with the pathogenicity was evident by the cluster analysis. In addition, there was no tight association between the pathogenicity and the sampling season of South American populations. Thus, diversity of the pathogenicity was apparent in 59 South American soybean rust populations, and the South American populations were not closely related to the Japanese samples used in this study.

Reactions of the soybean differentials to $P$. pachyrhizi from South America

Three Rpp1-carrying differentials, PI 200492 (differential 1), PI 368039 (differential 2), and PI 587886 (differential 11) produced a resistant reaction to only a few $P$. pachyrhizi populations $(1.8-14 \%)$ from the three countries. In contrast, PI 587880A (differential 10), which likely possesses a different Rppl allele from those of the other three Rppl-carrying differentials, had the highest level of resistance to the rust populations among the Rpp-carrying differentials. Resistant reaction in PI 230970 (differential 3) and PI 417125 (differential 4) both carrying Rpp2, and PI 462312 (differential 5) carrying Rpp3 was caused by 24 , 28 , and $22 \%$ of the South American populations, respectively. Differential responses to some rust populations were displayed among the four Rppl-encoding differentials and between two Rpp 2 differentials (Tables 4, 5, 6). PI 459025 (differential 6) and Shiranui (differential 7) with Rpp4 and $R p p 5$, respectively, were more effective to the rust populations from the three countries than the Rpp1-Rpp3-carrying differentials except for PI 587880A. Although the presence of Rpp resistance gene(s) in PI 416764 (differential 8), PI 587855 (differential 9), PI 587905 (differential 12), and PI 594767 (differential 13) is unknown, resistance levels varied among these differentials (Tables $4,5,6$ ). These Rpp-unknown differentials except for PI 416764 showed a resistant reaction to 78-96\% of all populations. BRS 154 (differential 14), TK5 (differential 15), and Wayne (differential 16) displayed a susceptible or intermediate reaction to most of the rust populations from the three countries, but a resistant reaction to some other populations (Tables 5,6). The two differentials were not appropriate as susceptible checks but would be useful to identify pathogenic variants in South American P. pachyrhizi; only BRS 154 is useful as a susceptible check for the evaluation system.

\section{Discussion}

In this study, we presented the first comparative analysis of soybean rust pathogenicity in three South American countries: Argentina, Brazil, and Paraguay. To understand 


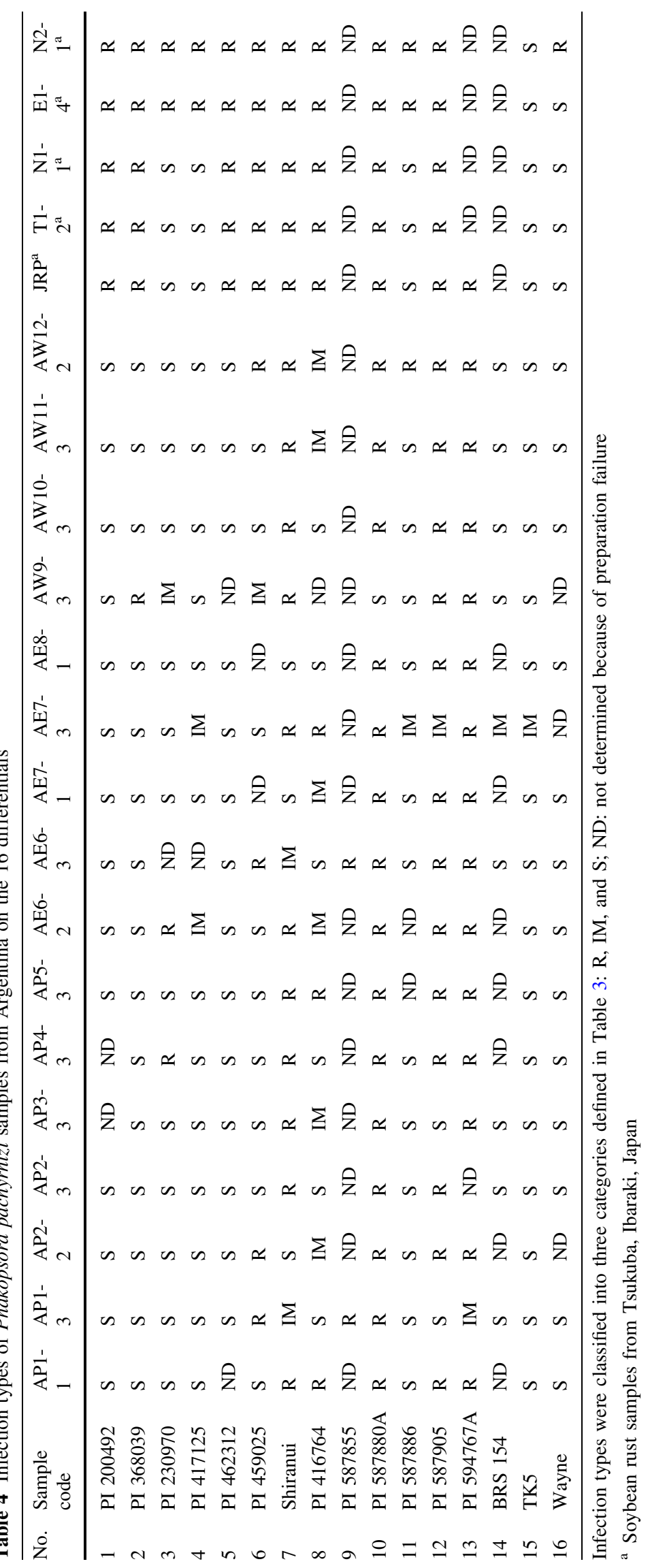




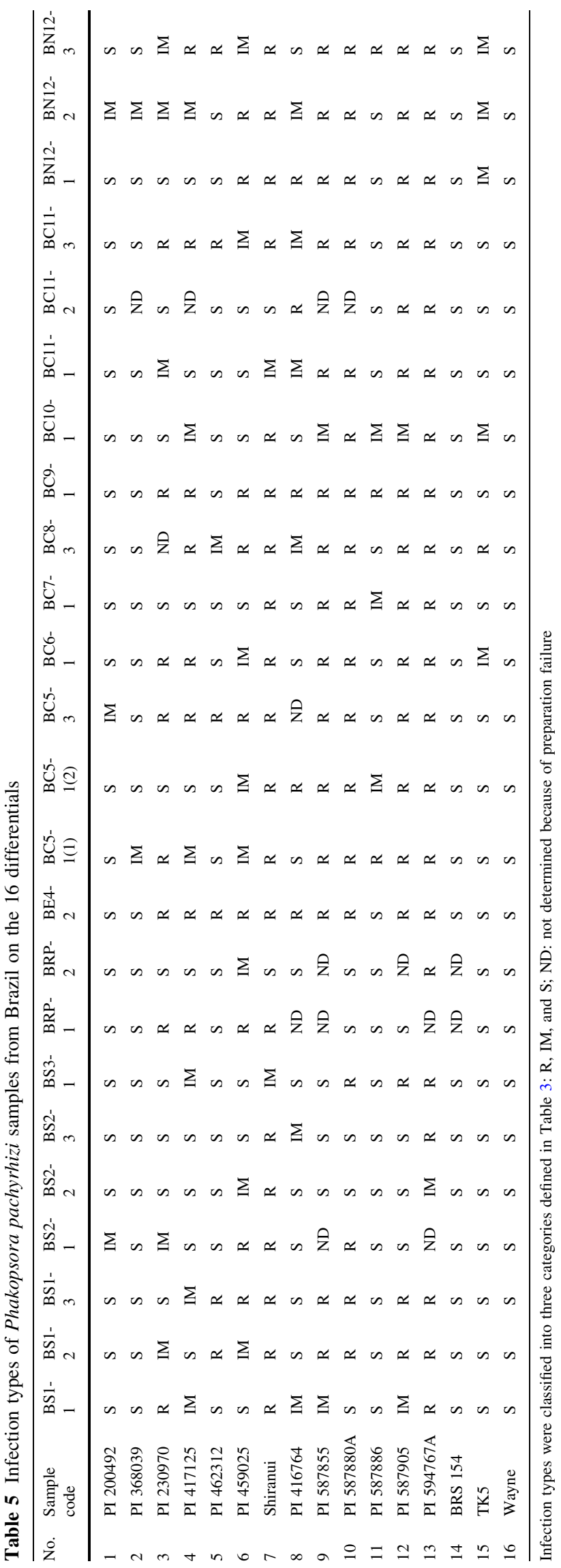

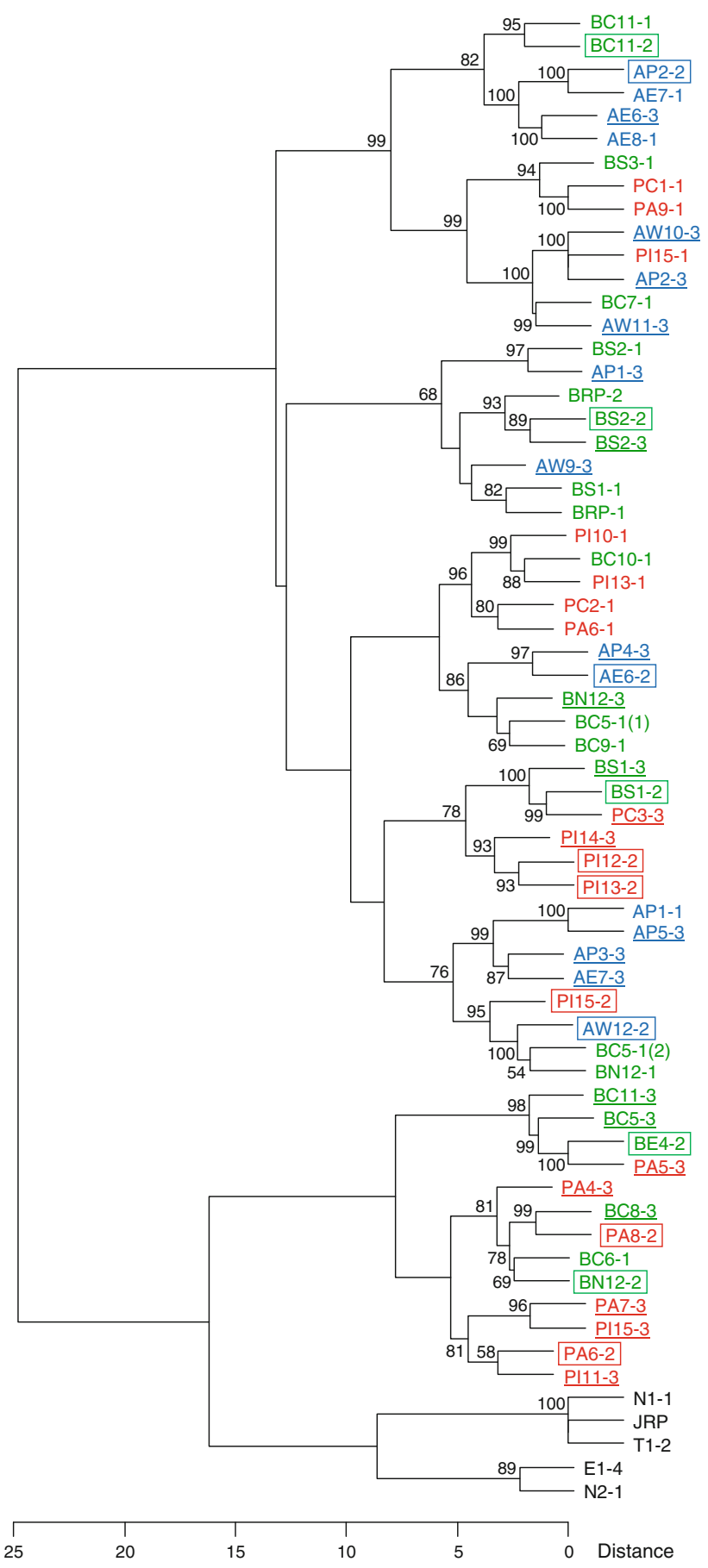

Fig. 3 Relationships of 16 Argentinean, 24 Brazilian, and 19 Paraguayan soybean rust populations based on pathogenicity to differentials. Numbers at the nodes indicate AU $p$ values $(>50 \%)$ generated by 10,000 multiscale bootstrap resamplings. Rust populations from Argentina, Brazil, and Paraguay are indicated by blue, green, and red letters, respectively. Five rust samples from Japan (black letter) are also included in the analysis. The sampling seasons are shown by different letter styles: the 2007/2008 season, normal; the 2008/2009 season, with frame; the 2009/2010 season, underlined 
pathogenic variation of $P$. pachyrhizi in South America, we developed an evaluation system for resistance to soybean rust and used it for all rust samples. Comparison of the pathogenicity profiles of 59 rust populations from the three countries revealed substantial pathogenic variation in the $P$. pachyrhizi populations infecting soybean in South America. In addition to the geographical variation of the pathogens in the three countries, pathogenicity of rust populations with the same geographical origin varied among the three cropping seasons (2007/2008-2009/2010). Of the 16 differentials, PI 587880A (Rppl), Shiranui (Rpp5), and three Rpp-unknown PIs displayed high levels of resistance to the rust populations. This study provides important information about the compositions of the $P$. pachyrhizi populations present in Argentina, Brazil, and Paraguay, which threaten the soybean industry worldwide.

An evaluation system for disease resistance is important for assessing pathogenicity and/or virulence in the causal pathogen populations. We developed a common evaluation system for resistance to soybean rust from three South American countries on the basis of the method of Yamanaka et al. (2010). Resistance to soybean rust was evaluated primarily by qualitative measures such as lesion appearance and color (Bromfield 1984; Burdon and Speer 1984; Yeh 1983). We used the presence or absence of lesions on the inoculated plants as one of the evaluation parameters, because the lesion color rating is most likely to be influenced by environmental factors (Yamanaka et al. 2010) and subjective evaluation by investigators. Four characters related to disease resistance, NoU, frequency of lesions with uredinia, frequency of open uredinia, and SL, were significantly correlated with one another (Yamanaka et al. 2010); therefore, only NoU and SL were included in our system. Such quantitative evaluation parameters are necessary to score an intermediate reaction that is difficult to be classified into either RB or TAN types (Bonde et al. 2006) and have been used to determine soybean susceptibility/resistance to the rust (Bonde et al. 2006; Miles et al. 2011; Pham et al. 2009; Yamaoka et al. 2002). The evaluation system consisting of the three parameters has been useful to simultaneously compare data from Argentina, Brazil, and Paraguay and may be applicable to P. pachyrhizi populations beyond these countries. For further clarifying the pathogenicity and/or virulence of South American populations, the establishment of an evaluation system for pathogen virulence solely using quantitative measures such as the NoU per unit leaf tissue and the addition of differentials carrying newly identified $R p p$ genes such as Rpp6 to the existing differential set will be required ( $\mathrm{Li}$ et al. 2012; Twizeyimana et al. 2009). Construction of isogenic lines for each of the Rpp genes or alleles, followed by their use as host differentials may minimize effects due to variation in the genetic background of the differential set, leading to the development of a more robust evaluation system for soybean rust resistance.

In $59 P$. pachyrhizi populations collected in Argentina, Brazil, and Paraguay, only two pairs of the rust populations showed identical pathogenicity profiles in the 16 differentials. Pathogenic variation of South American populations was detected within each country and among countries, as shown in several other studies (Bonde et al. 2006; Pham et al. 2009; Twizeyimana and Hartman 2012; Twizeyimana et al. 2009; Yamaoka et al. 2002). Although some combinations of the rust populations showed similar reaction patterns in the differentials, the complex composition of the pathogen populations was apparent in the three countries. Kato and Yorinori (2008) suggested a high level of pathogenic variation in soybean rust of Brazil, which is consistent with our results that all 24 Brazilian populations differed in pathogenicity. In South America, there was no correlation of $P$. pachyrhizi pathogenicity with the geographical origin of the populations. Likewise, Pham et al. (2009) found no association between pathogenicity and geographical origins of the rust isolates used. This study also demonstrated pathogenic variation of the $P$. pachyrhizi populations with the same geographical origin but different temporal origins. Yorinori (2008) noted that the $P$. pachyrhizi population structure in Brazil had changed within a few years after the first occurrence of the disease, and the new pathogen population was highly virulent to germplasm carrying Rpp genes. During the three seasons of this study, such temporal changes in pathogenicity of the rust populations to the Rpp-harboring differentials occurred in Argentina, Brazil, and Paraguay. Paraguayan populations in the 2007/2008 season induced susceptible reactions in 4-6 differentials carrying the Rppl-Rpp4 genes, which had been effective in the country in the 2001/2002 season (Yorinori 2008). In this study, we analyzed pathogenicity of $P$. pachyrhizi populations from the three South American countries in the 2007/2008-2009/2010 seasons, which provides a useful data set sufficient for comparing pathogenicity data from future monitoring of the pathogen populations.

The pathogenic variation of the $P$. pachyrhizi populations detected in this study probably reflects the diversity of the pathogen races or pathotypes in South America. Unlike highly specialized rust fungi, $P$. pachyrhizi can infect a broad range of leguminous plants (Goellner et al. 2010; Ono et al. 1992; Slaminko et al. 2008). Twizeyimana et al. (2009) pointed to a diversification in the pathogen population in response to the diversity in the host population in a soybean agroecosystem of Nigeria. Vittal et al. (2012) provided evidence of hyphal anastomosis followed by nuclear migration in $P$. pachyrhizi, suggesting that a parasexual cycle may be important for the development of genetic diversity in virulence. In South America, a 


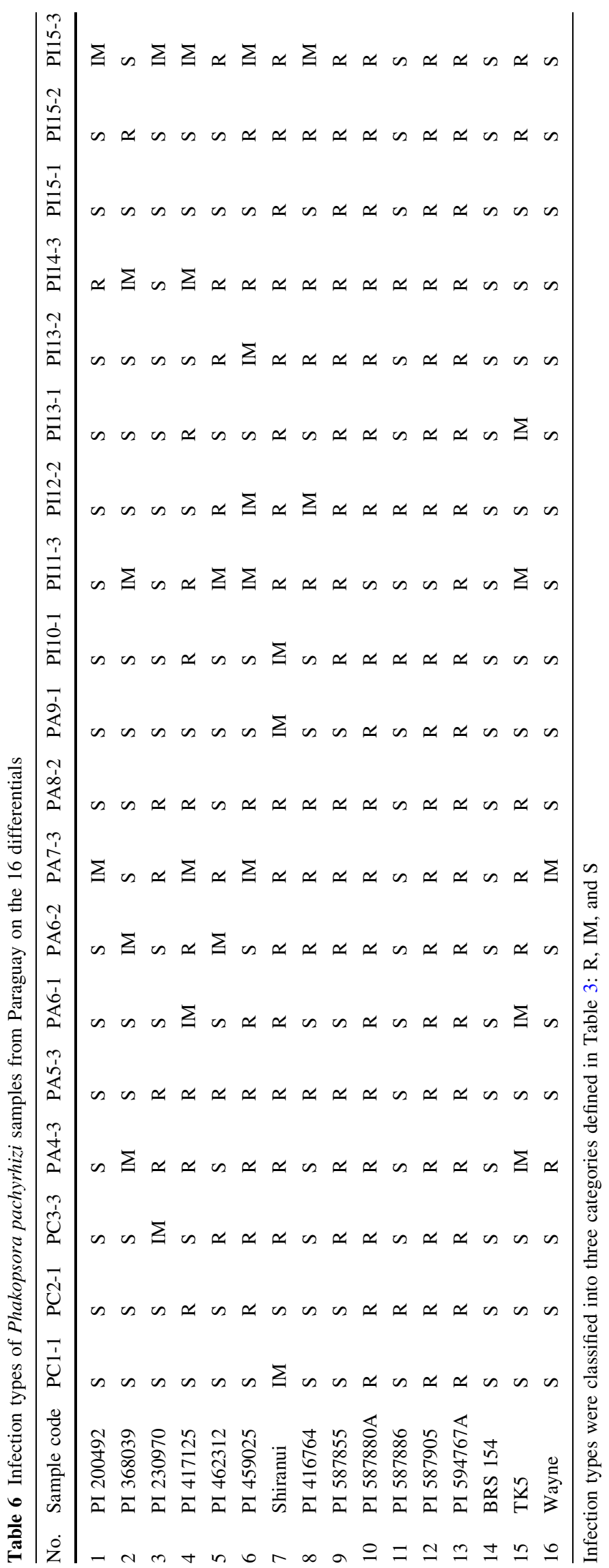


continent dominated by tropical and subtropical climatic zones with no severe winter, host plant connectivity by the co-occurrence of soybean and alternative hosts would contribute to maintain the fungal life cycle, and in combination with the genetic variability, it might play an important role in fostering the pathogenic diversity of P. pachyrhizi.

This study revealed that Rppl-Rpp4 genes have performed poorly against recent $P$. pachyrhizi populations in Argentina, Brazil, and Paraguay. In the four Rppl-carrying differentials, the responses of PI 587880A to the rust populations differed highly from the other three differentials (PI 200492, PI 368039, and PI 587886), and the result supports the finding of Ray et al. (2009) that PI 587880A harbors a different allele of Rppl from PI 200492. The responses to some rust populations also differed among the other three Rppl differentials and between two Rpp2 differentials, which may indicate that these differentials carry a different allele of Rppl or Rpp2, like Rpplc? in PI 587886 (Li et al. 2012; Ray et al. 2009) or an additional resistance gene (McLean and Byth 1980). Yamanaka et al. (2010) noted that among the five Rpp genes, only Rpp4 and Rpp 5 will be useful in breeding soybean rust resistant cultivars in Brazil. In contrast, Rppl, Rpp2, and Rpp3 were more effective to $P$. pachyrhizi isolates collected in the United States in 2006-2009 than Rpp4 and Rpp5 (Twizeyimana and Hartman 2012). We demonstrated that Shiranui carrying Rpp5 and four additional PIs (PI 587855, PI 587880A carrying Rppl, PI 587905, and PI 594767A) were highly resistant in the three countries. Rpp-unknown soybean lines expressing a high level of soybean rust resistance have been reported (Li 2009; Miles et al. 2006; Paul and Hartman 2009; Yamanaka et al. 2010), and recently Rpp6 has been identified in one of the lines, PI 567102B ( $\mathrm{Li}$ et al. 2012). Because the number of resistant resources in the pathosystem is limited, compared with the pathogenic differentiation of $P$. pachyrhizi, the highly resistant $R p p$-unknown differentials identified in this study will become useful sources for breeding new resistant cultivars in South America. Soybean rust control using single Rpp genes may not be sustainable in these countries; therefore, pyramiding multiple $R p p$ genes into a cultivar and using incomplete or partial resistance may assist in developing cultivars with more longer lasting resistance.

\footnotetext{
Acknowledgments We gratefully acknowledge Tatiani Janegitz, Maurício Sorge Pereira do Nascimento, and greenhouse facility staff of EMBRAPA Soja, and Hernán Russian of EEA-Pergamino, INTA, for their technical assistance. The authors also thank Enago (http://www.enago.jp/) for the English language review. This research was supported by the JIRCAS Research Project entitled "Identification of Stable Resistance to Soybean Rust for South America" and "Development of Breeding Technologies toward Improved Production and Stable Supply of Upland Crops".
}

\section{References}

Bonde MR, Nester SE, Austin CN, Stone CL, Frederick RD, Hartman GL, Miles MR (2006) Evaluation of virulence of Phakopsora pachyrhizi and P. meibomiae isolates. Plant Dis 90:708-716

Bromfield KR (eds) (1984) Soybean rust, Monograph No. 11. American Phytopathological Society Press, St. Paul

Burdon JJ, Speer SS (1984) A set of differential Glycine hosts for the identification of races of Phakopsora pachyrhizi Syd. Euphytica 33:891-896

FAOSTAT (2008) FAOSTAT statistical databases. Food and Agriculture Organization of the United Nations, Rome. http://faostat. fao.org/site/291/default.aspx. (cited September 2012)

Garcia A, Calvo ÉS, Souza Kiihl RA, Harada A, Hiromoto DM, Vieira LGE (2008) Molecular mapping of soybean rust (Phakopsora pachyrhizi) resistance genes: discovery of a novel locus and alleles. Theor Appl Genet 117:545-553

Goellner K, Loehrer M, Langenbach C, Conrath U, Koch E, Schaffrath U (2010) Phakopsora pachyrhizi, the causal agent of Asian soybean rust. Mol Plant Pathol 11:169-177

Hartman GL, Miles MR, Frederick RD (2005) Breeding for resistance to soybean rust. Plant Dis 89:664-666

Hartwig EE (1986) Identification of a fourth major gene conferring resistance to soybean rust. Crop Sci 26:1135-1136

Hartwig EE, Bromfield KR (1983) Relationships among three genes conferring specific resistance to rust in soybeans. Crop Sci 23:237-239

Isard SA, Gage SH, Comtois P, Russo JM (2005) Principles of the atmospheric pathway for invasive species applied to soybean rust. Bioscience 55:851-861

Ivancovich A (2005) Soybean rust in Argentina. Plant Dis 89:667-668

Kato M, Yorinori JT (2008) A study on a race composition of Phakopsora pachyrhizi in Brazil: a difficulty of race identification. In: Kudo H, Suenaga K, Soares RM, Toledo A (eds) JIRCAS Working Report No. 58: facing the challenge of soybean rust in South America. Japan International Research Center for Agricultural Sciences (JIRCAS), Tsukuba, pp 94-98

Laperuta LC, Arias CAA, Ribeiro AS, Rachid BF, Pierozzi PHB, de Toledo JFF, Pípolo AE, Carneiro GES (2008) New genes conferring resistance to Asian soybean rust: allelic testing for the Rpp2 and Rpp4 loci. Pesq Agropec Bras Brasília 43:1741-1747

Li S (2009) Reaction of soybean rust-resistant lines identified in Paraguay to Mississippi isolates of Phakopsora pachyrhizi. Crop Sci 49:887-894

Li S, Smith JR, Ray JD, Frederick RD (2012) Identification of a new soybean rust resistance gene in PI 567102B. Theor Appl Genet 125:133-142

Lin SY (1966) Studies on the physiologic races of soybean rust fungus, Phakopsora pachyrhizi Syd (in Chinese with English summary). J Taiwan Agric Res 15:24-28

McLean RJ, Byth DE (1980) Inheritance of resistance to rust (Phakopsora pachyrhizi) in soybeans. Aust J Agric Res 31:951-956

Miles MR, Frederick RD, Hartman GL (2006) Evaluation of soybean germplasm for resistance to Phakopsora pachyrhizi. Plant Health Prog. doi:10.1094/PHP-2006-0104-01-RS

Miles MR, Bonde MR, Nester SE, Berner DK, Frederick RD, Hartman GL (2011) Characterizing resistance to Phakopsora pachyrhizi in soybean. Plant Dis 95:577-581

Ono Y, Buriticá P, Hennen JF (1992) Delimitation of Phakopsora, Physopella and Cerotelium and their species on Leguminosae. Mycol Res 96:825-850

Paul C, Hartman GL (2009) Sources of soybean rust resistance challenged with single-spored isolates of Phakopsora pachyrhizi. Crop Sci 49:1781-1785 
Pham TA, Miles MR, Frederick RD, Hill CB, Hartman GL (2009) Differential responses of resistant soybean entries to isolates of Phakopsora pachyrhizi. Plant Dis 93:224-228

R Development Core Team (2011) R: a language and environment for statistical computing. R Foundation for Statistical Computing, Vienna. http://www.r-project.org/. (cited May 2011)

Ray JD, Morel W, Smith JR, Frederick RD, Milles MR (2009) Genetics and mapping of adult plant rust resistance in soybean PI 587886 and PI 587880A. Theor Appl Genet 119:271-280

Schneider RW, Hollier CA, Whitam HK, Palm ME, McKemy JM, Hernandez JR, Levy L, DeVries-Paterson R (2005) First report of soybean rust caused by Phakopsora pachyrhizi in the continental United States. Plant Dis 89:774

Slaminko TL, Miles MR, Frederick RD, Bonde MR, Hartman GL (2008) New legume hosts of Phakopsora pachyrhizi based on greenhouse evaluations. Plant Dis 92:767-771

Suzuki R, Shimodaira H (2006) Pvclust: an R package for assessing the uncertainty in hierarchical clustering. Bioinformatics 22:1540-1542

Twizeyimana M, Hartman GL (2012) Pathogenic variation of Phakopsora pachyrhizi isolates on soybean in the United States from 2006 to 2009. Plant Dis 96:75-81

Twizeyimana M, Ojiambo PS, Sonder K, Ikotun T, Hartman GL, Bandyopadhyay R (2009) Pathogenic variation of Phakopsora pachyrhizi infecting soybean in Nigeria. Phytopathology 99:353-361
Vittal R, Yang H-C, Hartman GL (2012) Anastomosis of germ tubes and migration of nuclei in germ tube networks of the soybean rust pathogen, Phakopsora pachyrhizi. Eur J Plant Pathol 132:163-167

Yamanaka N, Yamaoka Y, Kato M, Lemos NG, Passianotto ALL, Santos JVM, Benitez ER, Abdelnoor RV, Soares RM, Suenaga K (2010) Development of classification criteria for resistance to soybean rust and differences in virulence among Japanese and Brazilian rust populations. Trop Plant Pathol 35:153-162

Yamaoka Y, Fujiwara Y, Kakishima M, Katsuya K, Yamada K, Hagiwara H (2002) Pathogenic races of Phakopsora pachyrhizi on soybean and wild host plants collected in Japan. J Gen Plant Pathol 68:52-56

Yeh CC (1983) Physiological races of Phakopsora pachyrhizi in Taiwan. J Agric Res China 32:69-74

Yorinori JT (2008) Soybean germplasms with resistance and tolerance to Asian rust and screening methods. In: Kudo H, Suenaga K, Soares RM, Toledo A (eds) JIRCAS Working Report No. 58: facing the challenge of soybean rust in South America. Japan International Research Center for Agricultural Sciences (JIRCAS), Tsukuba, pp 70-87

Yorinori JT, Paiva WM, Frederick RD, Costamilan LM, Bertagnolli PF, Hartman GE, Godoy CV, Nune J Jr (2005) Epidemics of soybean rust (Phakopsora pachyrhizi) in Brazil and Paraguay from 2001 to 2003. Plant Dis 89:675-677 